\title{
308 エアクッション方式による自動車搬送用パレットの \\ 開発に関する研究

\author{
Study on Development of the Automobile Pallet \\ with Air Cushion Method
}

\section{○正 刀根 勝彦（北海道工大院） 正 白濱 芳朗（北海道工大） \\ Katsuhiko TONE and Yoshikuni SHIRAHAMA}

Hokkaido Institute of Technology, 7-15-4-1 Maeda Teine-ku Sapporo

\section{1. まえがき}

国内の個人における自動車の保有台数は年々増加し、これ に伴い駐車場確保の問題が益々深刻化してきている。とくに 都市の中心街の駐車場はスペースも小さいため収容台数も 限られる。しかし、中心街への駐車は大変便利であるため、 その利用率は減る傾向にはない。

駐車場における従来の車路幅、ドア開閉幅、車両旋回幅な どのスペースを有効利用し、収納台数の增加を図ることがで きれば、駐車効率は格段に引き上げられると考えられる。エ アクッションを利用した重量物移動用エアパレットは、摩擦 係数が極めて小さく、移動方向が自在に選択（その場旋回も 可能）できるなどの大きな特徵を持っており、人力でも動か すことが可能である。したがって、このパレットを車の移動 に利用できるならば、駐車効率の向上が大いに期待できる。 また、将来的には駐車場における自動車無人搬送装置とし、 駐車場の FA 化も視野に入れることができる。

これまで著者は、エアクッション方式による自動車搬送用 パレットの開発、性能試験および試作を行ってきた。本報告 では、第 5 号試作装置の性能試験結果について報告する。

\section{2. 自動車搬送用パレットの原理および設計製作}

自動車搬送用パレットの浮上原理は、図 1 に示すようにホ バークラフトの原理と同様で、本体底面のエアクッションに よりパレットを僅かに浮上させる。ただ、浮上パレットの久 点は、重量物をパレットの中心位置に積載しないとバランス が崩れ、パレットが傾くことにより内部の空気が漏れ浮上能 力が著しく低下することである。この欠点を防ぐために、図 2 に示すように、4つの独立したパレットを各パレットの中 央部に設けたボールジョイントにより接合し（図 3)、さらに フレームとガイドレールを取り付けて一体化した独自の方 法を採用している。

この方式では荷重はパレット中心部に加わることになり、 各パレットのバランスが常に保たれ、床面のう称りにも対応 できる。しかも浮上用動力の軽減も考えられる。この点が本 装置の大きな特徵である。搬送重量W、エアクッション面積 $\mathrm{A} 、$ エアクッション圧力 $\mathrm{p}$ の間の $\mathrm{W}=\mathrm{Ap}$ の関係より、エアク ッション面積を大きくすることによって低圧でも浮上可能 となる。しかし、面積 A の増加はスカートの周長を増加させ、 所定の性能を維持するためには空気供給量（風量）

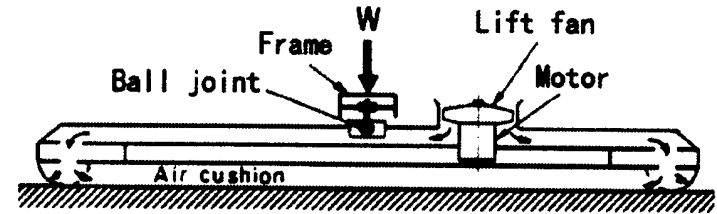

Fig. 1 Principle of the air-pallet
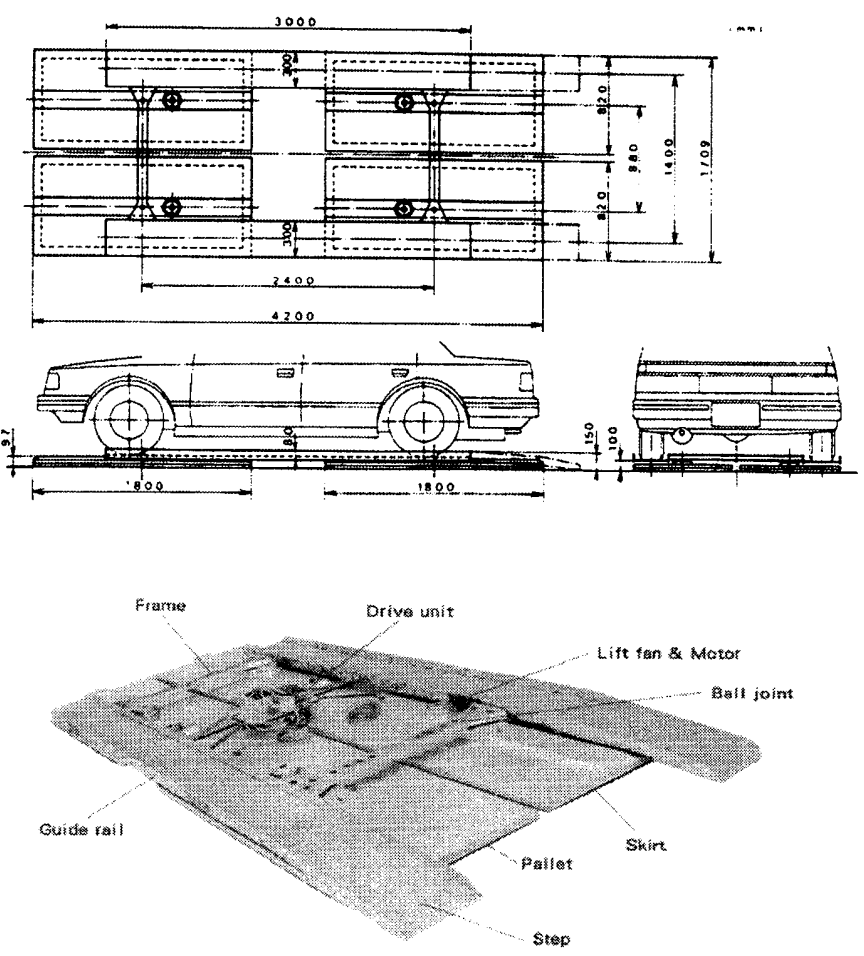

Fig.2 Schematic of the air-pallet

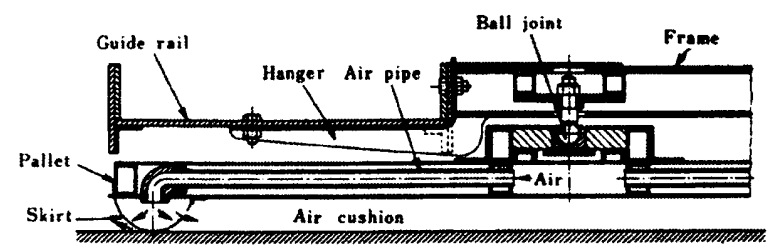

Fig.3 Connection used ball joint 
を増加させる必要がある。

パレット寸法は道路運送車両法による小型乗用車の寸法 （幅 $1.7 \mathrm{~m}$ 、長さ $4.7 \mathrm{~m}$ 以下）の基準を考慮して決定されて いる。パッレトの構造部材は、アルミニウム角パイプを桁材 とし、天板と底面にアルミ板を用いた。浮上用の遠心送風機 は、家庭用エアクリーナに内蔵されている遠心ファン付き単 層直巻モータュニット（100V-500W交直両用）を用いた。 各パレットに取付けた送風機の回転を制御するために電圧 制御器を試作した。これにより各パレット内の圧力が調整で き、各パッレトに加わる重量のアンバランスへの対処が可能 となる。パレットの浮上効率や路面の凹凸の影響を左右する スカート部の形状は種々あるが、本パレットではバック型を 採用した。

\section{3. 実験結果}

図 4 は性能試験の概略図である。パレットの性能は、次の 項目について調べた。1)搬送重量Wを変化させたときのパレ ットの搬送抵抗 $\mathrm{F}$ および搬送速度 S を計測する。曳航車（DC モータ内蔵、電圧制御により速度調整可能）とパレットをロ ードセルを介して連結し、パレットに初期搬送重量（車両重 量 $8000 \mathrm{~N}$ ）を負荷し、搬送抵抗を計測する。搬送重量を増加 させて同様の計測を行う。2）搬送重量を変化させたときの、 各パレット内の空気圧の変化を圧力変換器にて計測し、リニ アコーダに記録させる。

表 1 に計測結果を示す。実験搬送面はコンクリート床面 (金 テコ仕上げ) である。表は 2 種類の浮上用動力（4 パレット） における、搬送重量Wに対する搬送抵抗 $F(N)$ 、空気圧 $P(k P a)$ 、 搬送速度 S (m/min) の結果である。動力 $1.0 \mathrm{~kW}$ の場合、 $\mathrm{W}=8000 \mathrm{~N}$ ではパレット内の空気圧は $1.8 \mathrm{KPa}$ 、搬送抵抗（搬送 力）は静止状態から動き始めで $40 \mathrm{~N}$ と最大となり、その後 $25 \mathrm{~N}$ でほぼ一定となる。動力 $1.7 \mathrm{~kW}$ の場合にも同様の結果が得ら れており、搬送抵抗は $1.0 \mathrm{~kW}$ の場合と比較して、著しい差 はみられない。図 5 に搬送抵抗の搬送重量に対する変化を示 す。タイヤの転がり抵抗は、車両のみを率引したときの搬送 抵抗である。パレットの搬送抵抗は、タイヤの転がり抵抗に 比べ、たとえば、搬送重量 14KN では約 1/10 と非常に小さく、 エアクッション方式によるパレットの搬送力は人力で十分 であり、搬送能力が著しく優れていることが示されている。

\section{4.あとがき}

本報告の結果を要約すると、

1) 搬送重量に対する搬送抵抗は極めて小さく $1 / 1000$ のオ一 ダーである。タイヤの転がり抵抗との比較では、搬送抵抗 は約 1/10と小さい。

2) ホバーハイトが $1 / 10 〜 1 / 100 \mathrm{~mm}$ と低いため、床面の条件は 表面粗さ、うねりおよび水平度に左右される。したがって、 これらを考慮した床施工が必要となる

\section{参考文献}

（1）中嶋智也, エアクッションを利用した搬送装置の力空力

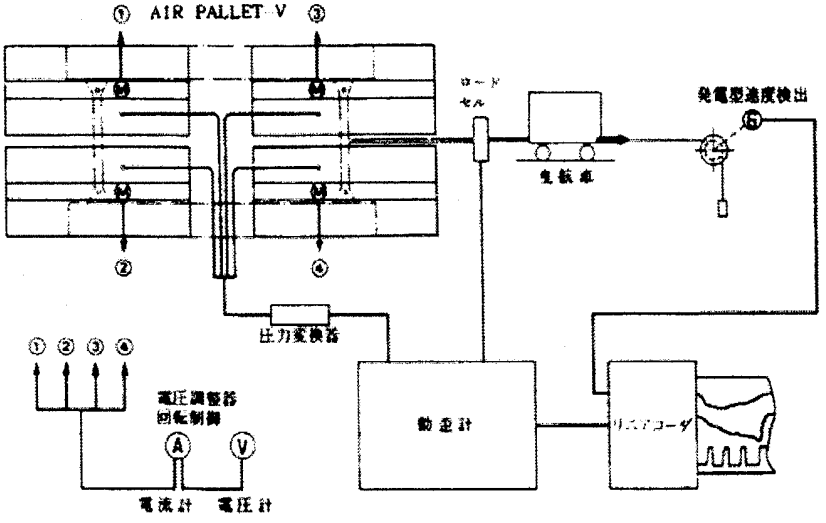

Fig4. Schematic of test procedure

Table.1 Performance of the air-pallet
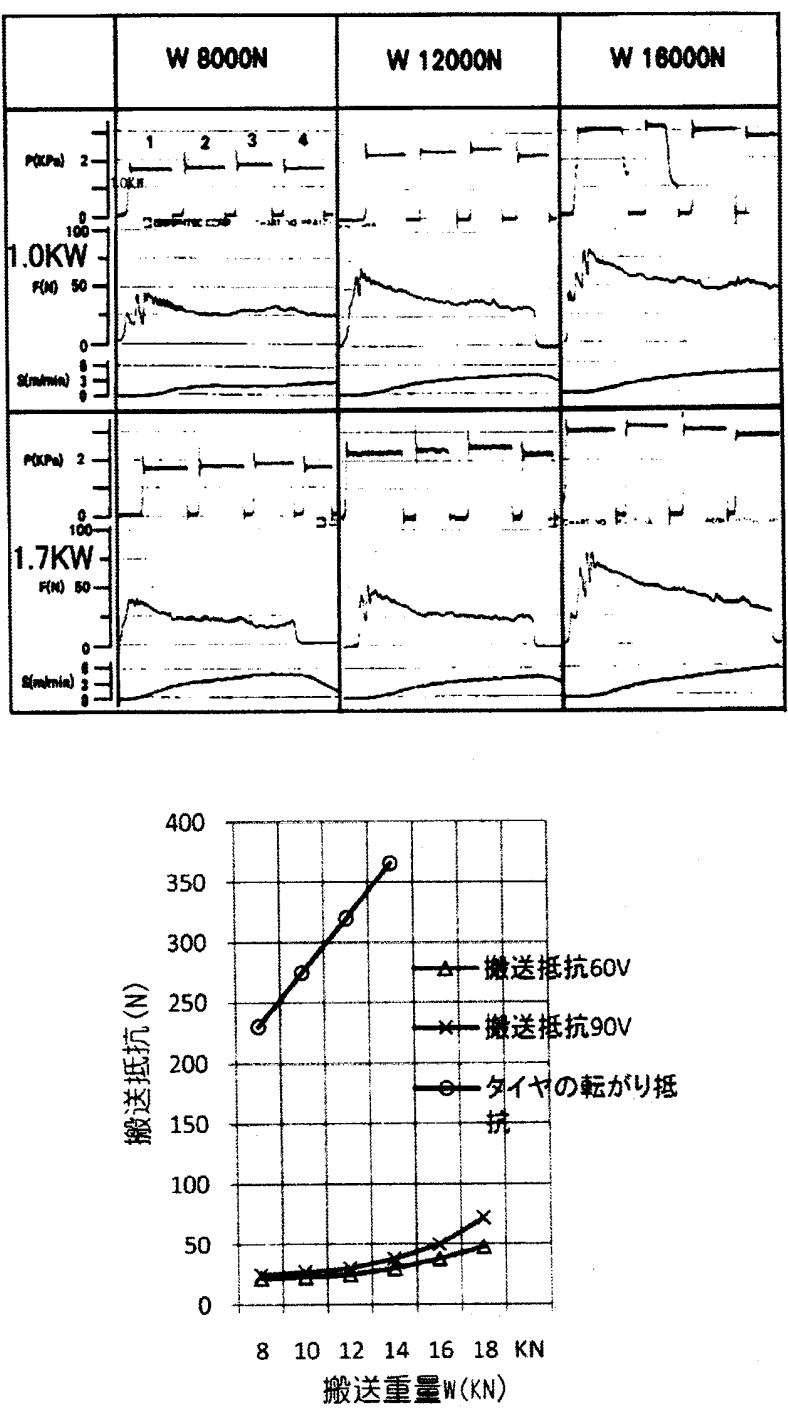

Fig.5 Transportation resistance for load

特性について, ACV の研究, VOL. 33, 2003.

（2）松尾健輔 - 金澤康 -千葉浩充 ·大島健二、高加重を受 けるエアパッドの動特性について, ACV の研究, VOL. 34, 2004. 